\title{
Policy of Land Registration Oriented in Social Justice in Indonesia
}

\author{
Sri Suhediningsih ${ }^{1 \mathrm{a}}$, Suteki $^{1 \mathrm{~b}}$, Sukirno $^{1 \mathrm{c}}$ \\ ${ }^{1}$ Faculty of Law, Universitas Diponegoro, Semarang, Indonesia \\ a suhediningsih@gmail.com
}

\begin{abstract}
Sociologically, land registration is highly demanded in relation to the growing economy of the people and the national economy. In relation to these advances the demand towards legal certainty is increasingly felt. This certainty is one of them manifested by the land certification. Recognizing the demand for services to the community requires the National Land Agency to organize the process of land registration in accordance with applicable legislation. The legal certainty becomes one of the important objectives in land registration in Indonesia.
\end{abstract}

Keywords-Policy; Land Registration; Social Justice

\section{INTRODUCTION}

The need for land continues to increase from year to year. This need is along with the increasing of development activities which at least contributes to increase the need for land for settlements and business activities.

So important and precious existence of land for the life of the community, so that the government has mandated in Article 19 paragraph (1) of Law Number 5 of 1960 years about on Basic Regulations of Agrarian Principles which reads that in order to guarantee a legal certainty related to land ownership by the Government, so that it was held registration of land throughout the Territory of the Republic of Indonesia in accordance with the provisions regulated by the Government Regulation.

This explanation becomes the main basis for the community to be able to own or use the existing land, and therefore necessary a registration of land as mandated in Article 19 paragraph (1) of Law Number 5 of 1960 years.

Sociologically, the registration of land is strongly demanded related to the advancement of the people's economy and the national economy. In relation to these advances, demands toward legal certainty are increasingly felt. This certainty, one of which is realized by land certification.

Realize the demands of service to the community, requires the National Land Agency to organize the process of land registration in accordance with existing legislation. The legal certainty becomes one of the important objectives in land registration in Indonesia[1].

For the above mentioned purposes, the land registration process has had a number of obligations for the registrant. While the reality in the community there are poor groups that can not always access the certification process of land rights. In this case, it should be the duty of the Land Deed Officer (PPAT) to facilitate, in accordance with the purpose of social justice for the community, including the poor.

Land registration which is a Government policy and implemented as an effort to align the land registration comprehensively for the community. These ways are regulated in Government Regulation Number 24 of 1997 years about Land Registry, they are : First, A land registration sistimatically is the first time of activities registration of land conducted simultaneously covering all objects of land registration that have not been registered in the territory or part of a village / district. Second, sporadic land registration is the first land registration activity concerning one or more objects of land registration within the territory or part of a village / district individually or massively

The focus of this study is the implementation of individual land registration where people who need land, and have not certified their Land Rights, may apply to obtain the Land Rights certificate.

The land registration process is shortly, whether it is the first land registration or transfer of land rights by the original owner of the certificate to the applicant. It can be seen that the costs that will appear in the land registration process can be divided into 5 positions, that is : 1) The cost of the Land Registry Process in the Land Office which includes certificate checking, measurement, and certificate issuance process for the new certificate. 2) PNBP fees, payable simultaneously at the time of the filing of the Right or Reverse Transition. The amount of PNBP is $1 / 1000$ (one per thousand / permill) of the Value of Object of Tax (NJOP) of land. 3) Income Tax, the amount of income tax is $5 \%$ of the amount of the transaction. Income tax must be paid before the sale and purchase certificate is signed. Payment of Income is made in the payee bank and then validated to the local tax office. This PPh is the responsibility of the seller, but there is also a buying and selling process that imposes an Income Tax to the buyer, if there is an earlier agreement. 4) BPHTB (Acquisition of Land and Building Rights) must be paid before the authentic deed / sale and purchase is signed. BPHTB is paid in the Regional Cash Office. 5) Authentic Deed Cost, is a service fee to PPAT maximal value of $1 \%$ of transaction value or object of registration of the land

This explanation gives an illustration that the cost to be issued by the community as a land registration applicant to obtain a land title certificate is quite large. This indirectly becomes an obstacle to the implementation of land registration in Indonesia thoroughly. These costs are a major factor in delaying the implementation of land registration. 
Other matters determined after the issuance of Government Regulation Number 24 of 1997 years is the position of PPAT should be responsible and protect the buyer of land. Unlike the previous circumstances, PPAT is only as fully independent and does not need to be responsible to anyone regarding the contents of the deed, and the submission of deed to the BPN Office is considered only as a service, not a liability.

Moving from the picture above, sociologically there are two things that are very important should be a concern in terms of people still register the land. First, the existence of PPAT becomes one thing related to access and expense that must be spent by society which use its services. Second, at any cost, some people feel that they must have a land certificate due to the interest of the land title certificate which will be used as a strong proof of ownership of land rights.

For the reasons above, people have to spend a lot of money. Related also with a complicated and time-consuming administration system with a high cost. Not infrequently because of this condition, there are some people who choose not to register the land.

Based on the description above that has been explained, then the problems that can be formulated is how the form of policy of registration of land oriented social justice to the poor?

\section{RESULT AND DISCUSSION}

\section{A. Public Policy Theory}

To examine the policy of land registration in Indonesia for the community then first explained about the theory of public policy. Many experts define policy and public policy.

According to Edi Suharto, that policy is a provision that contains the principles to direct the way the act is made in a planned and consistent in achieving certain goals[2].

According to David Easton, public policy is always born from three interrelated processes, namely input, black box, and output. The policy is derived from the manufacturing process based on certain inputs. This input will process in a black box which in this case allows many things to happen. Bargaining and attraction interests often occur in this black box. So what is called the output, born from such a variety of attraction. Conceptually, the formation of policies as outputs can be described by the Eastonian black box model that provides a model of a political system that greatly influences the "policy study (output) of the 1960s in conceptualizing the relationship between policy-making, policy output and its environment" wider. The main characteristic of the Estonian Model is that it sees the policy process in terms of input received, in the form of streams from the environment, mediated through input channels (parties, media, interest groups); demand in the political system (with inputs) and its conversion into outputs and policy outcomes[3].

\section{B. The Land Registry Policy in Social Justice Indonesia \\ In the State of Law of Indonesia it is emphasized that the development of the legal system relating to the}

management of natural resources in this regard including land should not be released from social reform. The legal system for natural resource management as contained in MPR Decree Number IX / 2001 on Agrarian Reform and Natural Resource Management is expected to be a means of planning, utilizing and controlling agrarian and natural resource use to achieve the greatest prosperity of the people. As mentioned in Article 33 of the 1945 Constitution of the Republic of Indonesia which reads as follows:

(1) The economy is constituted as a joint effort based on the principle of kinship.

(2) Production branches that are important for the state and which affect the livelihood of the people are controlled by the state.

(3) The earth and water and natural resources contained therein are controlled by the state and used for the greatest prosperity of the people.

(4) The national economy is organized on the basis of economic democracy with the principles of togetherness, fair efficiency, sustainability, environmental insight, independence, and by maintaining a balance of progress and national economic unity.

(5) Further provisions concerning the implementation of this article shall be governed by law

What is stipulated in Article 33 of the 1945 Constitution of the Republic of Indonesia is actually a moral text, especially the text of the earth, water, natural resources used for the greatest prosperity of the people; the economy is based on the principle of kinship, and production for the livelihood of the people controlled by the state[4].

The policy that became the object of this research is the agrarian law policy, especially in the regulation that refers to the government's desire to realize the equalization of registration of land rights in Indonesia which can be found in several regulations:

(1) The Law Number 5 of 1960 years on the Basic Regulation of Basic Agrarian Principles

(2) The Government Regulation Number 40 of 1996 years concerning Right to Use of Business, Right to Build and Use Right to Land

(3) The Government Regulation Number 24 of 1997 years concerning Land Registration

(4) The Government Regulation Number 46 of 2002 years on Tariff of Non-Tax State Revenue Applicable to the National Land Agency

(5) The Presidential Regulation Number 10 of 2006 years regarding National Land Agency

(6) The Regulation of the Minister of Agrarian Affairs / Head of National Land Affairs Agency Number 3 of 1997 years concerning Provisions on Implementation of Government Regulation Number 24 of 1997 years on Land Registration

(7) The Government Regulation Number 24 of 2016 years on Amendment to Government Regulation Number 37 of 1998 years concerning Regulation of Official Position of Land Deed Officer

Government policies contained in the various laws and regulations mentioned above have a linkage with each other that allows the establishment of a new policy on the 
implementation of land registration for free, especially for people who can not afford.

It should be understood that free land registration service has been mandated in Article 19 paragraph (4) of Law Number 5 of 1960 years on Basic Agrarian Law which states that the Government Regulation shall be regulated in the cost of the concerned with the registration referred to in paragraph (1) above, provided that the people unable to be exempted from payment of such fees.

Currently the free land registration is conducted by the Government through the National Land Agency Policy by establishing the National Agrarian Operations Project (PRONA) by providing free registration service for the underprivileged. PRONA Regulated in Decree of the Minister of Home Affairs Number 189/1981 on the National Agrarian Operations Project. The main objective of PRONA is to process mass land certification as a manifestation of an orderly chess program in the field of land that is implemented in an integrated manner and addressed to all levels of society, especially for the weak economic class, and to complete thoroughly on strategic land disputes. PRONA is established within the directorate general of agrarian affairs of the domestic department.

Regarding the fees charged for the land certificate in the implementation of PRONA is regulated in the Decree of the Minister of Agrarian Affairs / Head of the National Land Agency Number 4 of 1995 years concerning the Amendment of the Charges for the Granting of Land Rights Derived from the Granting of Land Rights, Conversion of Indigenous Land Rights, which became the Object of the National Agrarian Operations Project.

Under the provisions of Article 1 paragraph (1) of the Decree of the Minister of Agrarian Affairs / Head of the National Land Agency Number 4 of 1995 years stipulates that the granting of rights to state land to the community, affirmation / recognition of customary land and other lands designated as location of the national agrarian operations project in the framework of certifying the land mass, exempted from the obligation to pay income to the country as specified in the Regulation of the Minister of Home Affairs Number 1 of 1975 years, and to the recipient of the rights imposed the obligation to pay administrative costs. Under these provisions, land certification in the framework of PRONA is exempt from the obligation to pay income to the state, but in the case of receipt of land certificate result PRONA still have to pay administration fee

However, in practice, PRONA is accelerating the implementation of land registration by way of systematic land registration. In addition PRONA is a project proposed by the Government with the aim of providing the first land registration service with a simple process, easy, fast and cheap, but the problem is PRONA is not carried out continuously and is accidental at certain times and certain places that have been established by the government. While the need for land title certificates is always there every day and it is very ineffective to have to wait for PRONA to be held in certain areas.

This is a form of deviation from the mandate of legislation such as: Article 19 paragraph (4) of Law Number 5 of 1960 years on Basic Regulations - Basic Agrarian.
Given the facts above that the service of land registration has been the focus of the Government since the first time, but until now the implementation is still far from expectations and needed a firm policy to discipline the implementation of services of land registration with social justice such as Yusriyadi opinion that Indonesia will have to review the previous provisions and national development measures. This means that regulations that will be made in the future can accommodate the interests of the community that may not be accommodated in the previous regulation. Particularly in this case is the implementation of land registration which is the policy of the National Land Agency should be a priority for the implementation of land registration in accordance with the ideals and mandate of Article 33 paragraph 3 of the 1945 Constitution of the State of the Republic of Indonesia[5].

In line with the above, then how the service of land registration that meets the principle of justice is can be implemented if not through the PRONA program? This is the focus of this study. The author sees that there are other alternatives that can be done by the Government related to the implementation of land registration with social justice, which is by optimizing the participation of the parties involved in the implementation of land registration; one of them is the Land Deed Authority (PPAT).

Jurisdictionally, PPAT has the responsibility as a special official who is authorized to assist the Head of Land Office in the implementation of land registration. In addition, it has an obligation to provide services from its services without collecting fees for the underprivileged people as defined in Article 32 paragraph (2) of Government Regulation Number 24 of 2016 years on Amendment to Government Regulation Number 37 of 1998 years on the Regulation of Officials of the Land Deed Authority which reads that PPAT and PPAT Temporary shall provide services without collecting fees to a person who can not afford.

The role of PPAT and PPAT Meanwhile, to provide services to poor people in the registration of land for free shows that there are social values that must be maintained for the realization of social justice for all communities in obtaining the same rights in terms of ownership of Land Rights certificate in the process land registration.

\section{CONCLUSION}

Based on the descriptions that have been described, it can be concluded that the policy of land registration based on social justice in Indonesia is through policies in the field of law as outlined in various laws and regulations. The Law Number 5 of 1960 years on Basic Regulation - Basic Agrarian is a legal policy that has one purpose to provide services to people who can not afford to register their land for free. To follow up the provisions stipulated in Law Number 5 of 1960 years concerning Basic Regulations - Basic Agrarian Regarding the registration of land, the Government issued Government Regulation Number 24 of 2016 years on Amendment to Government Regulation Number 37 of 1998 years on the Regulation of Officials of the Land Deed Authority which 
obliges the Land Deed Officials (PPAT) to provide services to people who are unable to register land for free of charge.

\section{REFERENCES}

[1] Adrian Sutedi, Sertifikat Hak Atas Tanah, Cetakan Ketiga. Jakarta: Sinar Grafika, 2014.

[2] Edi Suharto, Kebijakan Sosial Sebagai Kebijakan Publik, Kebijakan Sosial Sebagai Kebijakan Publik. Bandung: Alfabeta, 2008.
[3] Wayne Easton, Public Policy : Pengantar Teori dan Praktik Analisis Kebijakan. Jakarta: Kencana, 2006.

[4] Satjipto Rahardjo, Mendudukkan UUD: Suatu Pembahasan dari Optik Ilmu Hukum Umum. Semarang: Badan Penerbit Universitas Diponegoro, 2007.

[5] Yusriyadi, Industrialisasi dan Perubahan Fungsi Sosial Hak Milik Atas Tanah. Yogyakarta: Genta Publishing, 2010. 